\title{
Studi Etnofarmasi Tanaman Obat Untuk Perawatan Dan Penumbuh Rambut Pada Beberapa Daerah Di Indonesia
}

Penulis

Afiliasi
Zulpakor Oktoba

Departemen Biologi Farmasi, Fakultas Farmasi, Universitas Padjadjaran

\section{Kata Kunci \\ - Etnofarmasi \\ P Perawatan rambut \\ - Tumbuhan obat}

Diterima 7 Juli 2017

Direvisi 29 Desember 2017

Disetujui 28 September 2018

* Penulis Koresponding Zulpakor Oktoba Jl. Raya Bandung Sumedang KM 21, Jatinangor 45363 zulpakor16001@mail.unpad.a c.id

\section{ABSTRAK}

Studi etnofarmasi merupakan pendekatan yang digunakan untuk mengeksplorasi pengetahuan lokal komunitas tertentu dalam hal pemanfaatan tumbuhan obat. Artikel ini membahas tentang metode pengobatan dan tanaman obat yang digunakan untuk perawatan dan pemeliharaan rambut pada beberapa etnis di Indonesia yaitu Aceh, Mandailing, Rejang, Melayu kerinci, Melayu, Jawa, Using, Dayak (Kanayant, Tunjung, Malinau), Bali, Kaili (Ledo, Moma), Seko, Banggai, Sigi. Selain itu studi ini juga bermanfaat untuk mengetahui obat dari bahan alam yang belum banyak diketahui bioaktivitasnya. Metode yang digunakan adalah studi literatur, sedangkan data yang digunakan adalah artikel, database dan textbook yang dipublikasikan dari tahun 1993 sampai 2017. Pencarian informasi literatur dilakukan menggunakan mesin pencarian elektronik artikel dan jurnal penelitian yang dipublikasikan pada beberapa situs, seperti Google, Pubmed, NCBI, Elsevier, dan lain-lain. Hasil data yang didapat disimpulkan bahwa ada 23 jenis spesies tanaman yang digunakan untuk perawatan dan penumbuh rambut dari 20 famili.

\section{PENDAHULUAN}

Indonesia yang dikenal sebagai negara megabiodiversity tidak hanya kaya akan keanekaragaman flora, fauna dan ekosistemnya tetapi juga memiliki keanekaragaman suku/etnis dengan pengetahuan tradisional dan budaya yang berbeda dan unik tersebar dari Sabang hingga Merauke. Kurangnya dokumentasi mengenai penggunaan tumbuhan obat oleh komunitas tertentu menyebabkan sulitnya pelestarian obat tradisional tersebut (Rosita et al. 2007). Arus modernisasi masuknya budaya dari luar, terutama yang diadopsi oleh generasi muda membuat makin lunturnya pengetahuan lokal pada komunitas tertentu (Bodeker 2000; Windardi et al. 2006). Alternatif pendekatan yang dapat digunakan untuk menggali pengetahuan lokal komunitas tertentu mengenai penggunaan tumbuhan sebagai obat adalah dengan etnofarmasi. Melalui studi ini, 
dimungkinkan dilakukan penelusuran mengenai bahanbahan obat tradisional, dan cara penggunaannya sebagai penciri budaya dalam suatu komunitas tertentu (Pieroni et al. 2002).

Etnofarmasi merupakan suatu ilmu interdisipliner yang berhubungan dengan istilah farmasi dan budaya tertentu yang mengkarakterisasi penggunaan sediaan tersebut pada sejumlah kelompok manusia (Pieroni et al. 2002). Ilmu ini tidak hanya mencakup aspek botani dan farmakologi, namun juga fitokimia, galenika, penghantaran obat, toksikologi, klinis, farmasi praktis/antropologi, sejarah, dan aspek penelitian tumbuhan obat lainnya pada sistem kesehatan tradisional (Heinrich \& Bremner 2006). Etnofarmasi meliputi studi identifikasi, klasifikasi, kategorisasi kognitif terhadap bahan alam yang digunakan untuk pengobatan (etnobiologi), pembuatan sediaan farmasi (etnofarmasetika), penentuan aktivitas tertentu dari suatu sediaan (etnofarmakologi), dan aspek sosiomedis akibat penggunaan sediaan tersebut (etnomedisin) (Pieroni et al. 2002).

Rambut terdapat hampir pada seluruh bagian tubuh dan memiliki berbagai fungsi, antara lain fungsi estetika bagi manusia. Rambut sering disebut sebagai mahkota bagi wanita, sedangkan bagi pria, rambut mempengaruhi rasa percaya diri. Kerontokan rambut yang dapat mengakibatkan kebotakan merupakan salah satu problema yang paling dikhawatirkan setiap orang (Priskila 2012). Rambut terdiri atas akar dan tangkai rambut sedangkan akar rambut dialiri darah melalui syaraf sehingga rambut sensitif terhadap lingkungan, cuaca atau zat-zat kimia yang digunakan untuk tata rias rambut. Reaksi biokimia yang mempengaruhi pertumbuhan rambut terletak di bagian bawah akar (Azis \& Muktiningsih, 1999). Rambut mengalami daur pertumbuhan dan kerontokan yang berbeda pada setiap helainya. Meskipun kerontokan merupakan daur alami dari rambut, namun terkadang kuantitas dan frekuensi kerontokan menjadi meningkat sehingga terjadi kebotakan. Hal ini umumnya disebabkan oleh gangguan hormonal, efek samping obat, makanan yang dikonsumsi, dan stress (Mitsui 1992).

Masalah kerontokan rambut menurut para peneliti diatasi dengan cara inovasi menemukan formula kosmetik yang efektif. Hal ini berefek pada banyaknya kosmetika rambut yang dipasarkan, baik produk sintetis maupun produk herbal. Penggunaan bahan yang bersifat sintetis maupun produk herbal sudah banyak diproduksi. Penggunaan bahan yang bersifat sintetis pada produk kosmetika dinilai kurang aman karena dapat menimbulkan efek samping pada penggunaan jangka panjang seperti efek alergi (eksim ringan), patogenik, hingga karsinogenik (kanker) (Priskila 2012). Tanaman yang dapat berperan sebagai penumbuh rambut dan telah lama dikenal masyarakat Indonesia contohnya adalah kemiri dan kedelai. Perawatan rambut dengan bahan herbal telah dikenal sejak lama oleh etnis di Indonesia seperti etnis Wajak, etnis Baduy, etnis Jawa, etnis Batak, etnis Melayu, etnis Betawi, etnis Aceh, etnis Toraja, etnis rejang, etnis Bali, etnis Dayak dan etnis Papua. Berdasarkan pengetahuan umum yang sejak lama telah berkembang di masyarakat dan adanya slogan "back to nature" para peneliti tergerak untuk memanfaatkan bahan herbal dalam bidang kosmetik, selain dari bahan sintetis seperti minoksidil (Sawaya 1998).

Dalam rangka penemuan obat baru sebagai alternatif pengobatan kebotakan, maka dapat digunakan pendekatan etnofarmasi untuk menentukan jenis tumbuhan tertentu yang potensinya tinggi dan cara penggunaannya berdasarkan pengetahuan empiris yang diyakini oleh masyarakat di daerah-daerah tertentu. Dari hasil studi etnofarmasi tersebut, dapat dilakukan penelitian lebih lanjut untuk pengembangan tumbuhan obat terpilih. Review artikel ini bertujuan untuk memperoleh informasi dan dokumentasi keragaman jenis tumbuhan berkhasiat obat dan pemanfaatannya. Selain untuk keperluan pendokumentasian pengetahuan tradisional, juga diharapkan dapat menyumbangkan informasi bagi peminat etnofarmasi dalam mengembangkan teknologi pemanfaatan tumbuhan berkhasiat obat.

\section{METODE}

Sumber data dan strategi pencarian sebagai bahan review jurnal, penulis melakukan teknik pengumpulan data dengan studi literatur yang telah dipublikasikan dalam artikel, jurnal penelitian ilmiah serta text book sebelumnya. Sumber data yang digunakan adalah artikel, database dan textbook yang dipublikasikan dari tahun terakhir 1986-2017. Pencarian literatur dilakukan menggunakan mesin pencarian artikel dan jurnal penelitian yang dipublikasikan pada beberapa situs, seperti Google, Pubmed, NCBI, Elsevier, dan lain-lain. Hasil konsep ini memungkinkan kontribusinya dalam penemuan obat baru yang berasal dari tumbuhan tertentu berdasarkan penggunaannya oleh komunitas 
lokal tertentu, dalam rangka pencarian alternatif pengobatan (Heinrich \& Bremner 2006).

\section{HASIL DAN PEMBAHASAN}

Berdasarkan hasil kajian literatur didapatkan tanaman obat untuk perawatan dan penyubur atau penumbuh rambut pada Tabel 1.

Keragaman jenis tumbuhan obat yang dimanfaatkan pada beberapa etnis di Indonesia dalam penggunaannya untuk perawatan dan penumbuh atau penyubur rambut diidentifikasi sebanyak 23 jenis tumbuhan obat yang berasal dari 20 famili, terdapat kesamaan tanaman obat yang digunakan diantara beberapa suku yang ada di Indonesia seperti kemiri, lidah buaya, kelapa dan urang-aring dengan nama lokal yang berbeda.

\section{Kemiri (Aleurites moluccana L.)}

Buah kemiri oleh etnis Dayak sebagai penyubur rambut dengan membakar buahnya kemudian dioleskan ke rambut. Daging biji, daun dan akarnya mengandung saponin, flavonoida dan polifenol, disamping itu daging bijinya juga mengandung minyak lemak (Syamsuhidayat et al. 1991). Pemanfaatan di daerah lain sebagai obat flu, pilek, penumbuh rambut, anti kanker (Sangat et al. 2000). Kandungan di dalam biji kemiri antara lain: mineral, kalium, fosfor $200 \mathrm{mg}$, magnesium, dan kalsium 80 mg merupakan kandungan mineral yang mendominasi dalam biji kemiri. Kedua yaitu kandungan zat gizi mikro di dalam $100 \mathrm{gr}$ daging biji kemiri antara lain protein $19 \mathrm{gr}$, lemak $63 \mathrm{gr}$, vitamin B1 0,06 mg, dan karbohidrat 8 gr. Lalu yang ketiga adalah zat non-gizi yang menurut penelitian sangat bermanfaat bagi kesehatan yaitu polifenol, saponin, juga flavonoida (Ketaren 1986). Selain itu, kemiri juga mengandung mineral antara lain besi $2 \mathrm{mg}$, fosfor $200 \mathrm{mg}$, dan kalsium $80 \mathrm{mg}$ (Istriyani 2011). Asam amino yang paling menonjol pada kemiri yaitu asam glutamat ( $3.71 \mathrm{gr} / 100 \mathrm{gr}$ ) dan asam aspartat (1.68 $\mathrm{gr} / 100 \mathrm{gr}$ ). Saat ini minyak kemiri dengan kualitas tinggi sudah menjadi produk komersial utama dan dijual secara luas di industri kosmetika. Kemiri berfungsi mengatasi kerontokan rambut dengan mekanisme menguatkan akar rambut yang biasanya diproduksi dan dikemas dalam sediaan minyak rambut. Di Indonesia kemiri yang diekstrak menjadi minyak kemiri sudah lama dipercaya sebagian besar penduduk Indonesia sebagai penyubur dan mengurangi kerontokan rambut (Arlene 2013). Minyak kemiri mengandung sejumlah zat kimia yang berkhasiat untuk menyuburkan rambut, menghitamkan rambut secara alami, dan digunakan sebagai bahan baku sabun atau bahan bakar untuk penerangan, namun jarang digunakan untuk menggoreng (Prihandana et al. 2008). Hal ini disebabkan karena minyak kemiri mengandung asam hidrosianik yang bersifat racun. Oleh karena itu, kemiri digolongkan menjadi minyak lemak non-pangan (nonedible oil) (Prihandana et al. 2008). Buah kemiri tidak dapat langsung dimakan mentah karena beracun, yang disebabkan oleh toxalbumin (penghambat sintesis protein pada tubuh serta menyebabkan mual dan diare) (Ketaren, 1986). Persenyawaan toxalbumin dapat dihilangkan dengan cara pemanasan dan dapat dinetralkan dengan penambahan bumbu lainnya seperti garam, merica, dan terasi. Bila terjadi keracunan karena kemiri, dapat dinetralkan dengan meminum air kelapa. Minyak kemiri dapat digunakan sebagai minyak rambut dan di pulau Jawa sebagai bahan pembatik, dan juga untuk penerangan (Ketaren 1986).

\section{Lidah buaya (Aloe vera $\mathrm{L}$ )}

Penggunaan lidah buaya untuk menyuburkan rambut pada etnis Jawa dengan cara batang dikupas kemudian getah atau lendirnya dioleskan di kulit kepala. Kandungan kimia dari lidah buaya adalah aloin, barbaloin, isobarbaloin, aloeemodin, aloenin, aloesin. Khasiat lain dari lidah buaya adalah untuk mengobati sakit kepala, sembelit, kejang pada anak, batuk, kencing manis, peluruh haid. (Widyaningrum, 2011).

\section{Seledri (Apium gravolens $\mathrm{L}$ )}

Batang dan daun seledri dimanfaatkan oleh etnis rejang sebagai penyubur rambut dengan mengambil segenggam daun seledri kemudian di remas-remas, lalu dikeramaskan. Herba seledri secara empiris dapat mempengaruhi pertumbuhan rambut (Dalimartha 1999). Menurut beberapa penelitian yang telah dilakukan bahwa seledri berkhasiat memberikan efek dalam mempercepat pertumbuhan rambut (Winanti 2005; Sri Rahayu, 2007). Hasil dari Penelitian tersebut diketahui bahwa flavonoid dan saponin adalah senyawa kimia yang berperan dalam memacu pertumbuhan rambut. Saponin mempunyai kemampuan untuk membentuk busa yang berarti mampu membersihkan kulit dari kotoran serta sifatnya sebagai counteriritan, yang dapat meningkatkan sirkulasi darah perifer sehingga meningkatkan 
pertumbuhan rambut. Flavonoid mempunyai aktivitas sebagai bakterisid sehingga dapat mempercepat pertumbuhan rambut dan mencegah kerontokan (Marchaban 2007).
Lidah Mertua (Sanseviera trifasciata prai)

Pada Etnis Dayak Kanayant daun lidan mertua digunakan sebagai penyubur rambut. Manfaat lain dari daun lidah mertua dapat mengobati penyakit

Tabel 1. Tanaman obat untuk perawatan dan penyubur atau penumbuh rambut dari berbagai etnis di Indonesia

\begin{tabular}{|c|c|c|c|c|c|c|}
\hline No. & $\begin{array}{c}\text { Nama Lokal/Nama } \\
\text { Indonesia }\end{array}$ & Nama Jenis & Famili & $\begin{array}{c}\text { Bagian } \\
\text { yang } \\
\text { berguna }\end{array}$ & Kegunaan & Etnik \\
\hline 1. & $\begin{array}{l}\text { Perija } \\
\text { Kemiri } \\
\text { Sap'pi } \\
\text { Pelo }\end{array}$ & Aleurites mollucana (L.) Wild. & Euphorbiaceae & Buah & Penyubur rambut & $\begin{array}{c}\text { Dayak tunjung } \\
\text { Kaili Ledo } \\
\text { Seko } \\
\text { Kaili Moma } \\
\text { Sigi } \\
\text { Bali }\end{array}$ \\
\hline 2. & Lindah buaya & Aloe vera (L.) Burm.f. & Asphodelaceae & $\begin{array}{l}\text { Batang, } \\
\text { Getah }\end{array}$ & $\begin{array}{l}\text { Perawatan dan } \\
\text { penyubur rambut }\end{array}$ & $\begin{array}{c}\text { Banggai } \\
\text { Jawa } \\
\text { Bali } \\
\text { Seko } \\
\text { Melayu } \\
\text { Tradisional, } \\
\text { kerinci } \\
\text { Kaili } \\
\text { Toraja } \\
\text { Mandailing }\end{array}$ \\
\hline 3. & Pali-pali/sidaguri & Sida rhombifolia L. & Malvaceae & Daun & Penyubur rambut & Seko \\
\hline 4. & $\begin{array}{l}\text { Kelapa } \\
\text { Kelapa Hijau / Klopo } \\
\text { ljo } \\
\text { Kaluku }\end{array}$ & Cocos nucifera & Arecaceae & Buah & Penyubur rambut & $\begin{array}{c}\text { Bali } \\
\text { Jawa }\end{array}$ \\
\hline 5. & Jarak & Jatropha curcas L. & Euphorbiaceae & Buah & Penyubur rambut & $\begin{array}{l}\text { Bali } \\
\text { Rejang }\end{array}$ \\
\hline 6. & $\begin{array}{l}\text { Daun Teh-tehan/ } \\
\text { Kedondong cina }\end{array}$ & Polyscias fruticose & Araliaceae & Daun & Penyubur rambut & Bali \\
\hline 7. & Pacing & Costus speciosus & Zingiberaceae & Herba & Penyubur rambut & Bali \\
\hline 8. & Waru & Hibiscus tiliaceus & Malvaceae & Daun & Penyubur rambut & Bali \\
\hline 9. & Urang-Aring & Eclipta alba L. Hassk & Asteraceae & Daun & Penyubur rambut & $\begin{array}{c}\text { Bali } \\
\text { Sabang, Aceh }\end{array}$ \\
\hline & & Eclipta prostrata & & & & Jawa \\
\hline 10. & Pandan arum & Pandanus amaryllifolius & Pandanaceae & Daun & Penyubur rambut & Bali \\
\hline 11. & Akar wangi & Vetiveria zizanioides & Poaceae & Akar & Penyubur rambut & Bali \\
\hline 12. & Klabet & Trigonella foenum-graecum & Fabaceae & Biji & Penyubur rambut & Bali \\
\hline 13. & Sandat & Cananga odorata & Annonaceae & Bunga & Penyubur rambut & Bali \\
\hline 14. & Cempaka & Magnolia liliifera & Magnoliaceae & Bunga & Penyubur rambut & Bali \\
\hline 15. & Rambutan & Nephelium lappaceum & Sapindaceae & Daun & Penyubur rambut & Bali \\
\hline 16. & Pulai & Alstonia scholaris (L.) R. Br. & Apocynaceae & $\begin{array}{c}\text { Getah, } \\
\text { kulit } \\
\text { batang }\end{array}$ & Penyubur rambut & Melayu \\
\hline 17. & $\begin{array}{l}\text { Cabe rawit/Campli } \\
\text { cut }\end{array}$ & Capsicum frutescen & Solanaceae & $\begin{array}{l}\text { Daun } \\
\text { Daun }\end{array}$ & $\begin{array}{l}\text { Penyubur rambut } \\
\text { Penyubur rambut }\end{array}$ & $\begin{array}{l}\text { Sabang, Aceh } \\
\text { Rejang }\end{array}$ \\
\hline 18. & Seledri/Daun Sop & Apium gravolens L. & Apiaceae & Daun & Penyubur rambut & Rejang \\
\hline 19. & Lidah mertua & Sanseviera trifasciata prai & Asparagaceae & Daun & Penyubur rambut & Dayak Kanayant \\
\hline 20. & We bala/rutan merah & Asplenium cf. phyllitidis & Aspleniaceae & $\begin{array}{l}\text { Paku } \\
\text { (Daun) }\end{array}$ & Penyubur rambut & Malinau, Kaltim \\
\hline 21. & U'de Pa'deng & Gmelina sp & Verbenaceae & Daun & Penyubur rambut & Malinau, Kaltim \\
\hline 23. & Katuk & $\begin{array}{l}\text { Souropus androgynus (L.) } \\
\text { Merr }\end{array}$ & Euphorbiaceae & Daun & Penyubur rambut & $\begin{array}{c}\text { Using, } \\
\text { Banyuwangi }\end{array}$ \\
\hline
\end{tabular}


diantaranya influenza, batuk, radang saluran pernapasan, keseleo, luka terpukul, gigitan ular berbisa, borok, dan bisul (Widyaningrum 2011). Daun lidah mertua mengandung senyawa saponin, dan senyawa lain seperti abamagenin, kardenolin, dan polifenol (Putra 2013). Saponin berupa koloid yang larut dalam air dan berbusa setelah dikocok, memiliki rasa pahit. Saponin dapat menghemolisis atau menghancurkan sel-sel darah merah (Tyler et al. 1989). Saponin dalam tanaman lidah mertua bermanfaat untuk mempengaruhi kolagen, yaitu dalam menghambat produksi jaringan bekas luka yang berlebihan (Ulya 2012).

\section{Kelapa (Cocos nucifera $\mathrm{L}$ )}

Buah kelapa untuk khasiat menyuburkan rambut cara pengolahannya adalah dibakar, diambil minyaknya, dioleskan di kulit kepala. Pada etnis Using untuk menjaga kesehatan rambut sering menggunakan minyak kelapa (Cocos nucifera L.) sebagai bahan minyak rambut. Minyak kelapa mengandung trigliserida berupa asam laurat (45\%) (Robinson 1995). Trigliserida tersebut memiliki afinitas yang tinggi untuk menembus sampai pada kutikula dan korteks sel rambut serta dapat melapisi permukaan serat rambut. Hal tersebut menempatkan minyak kelapa sebagai bahan utama sebagai pelindung rambut dari kerusakan atau untuk merawat rambut yang rusak (Rele et al. 2003).

\section{Cabe rawit (Capsicum frutescen)}

Suku rejang memanfaatkan daun cabe rawit sebagai penumbuh rambut yaitu menggunakan daun muda, yang langsung ditempelkan pada bagian kepala. Daun cabe rawit (Capsicum frutescens L.) telah diindentifikasi mengandung senyawa glikon dan flavonoid (Yunita, 2012). Ekstrak daun cabe rawit memiliki senyawa aktif berupa flavonoid yang merupakan senyawa fenol yang terbesar dialam yang terdapat pada tumbuhan yang memiliki sifat antibakteri terhadap penghambatan pertumbuhan bakteri Escherichia coli. (Lestari et al. 2016).

\section{Daun Teh - tehan (Polyscias fruticose)}

Daun teh - tehan atau kedondong cina memiliki kandungan senyawa kimia seperti saponin, flavonoida, polifenol dan tanin. Tumbuhan ini biasanya di manfaatkan untuk peluruh air seni dan penyubur rambut (Sastrapradja et al. 1986).

\section{Pacing (Costus speciosus)}

Tumbuhan pacing memiliki kandungan senyawa kimia diosgenin (sapogenin steroid), tigogenin, dioscin, gacillin, sitosterol. Kegunaan tumbuhan ini untuk memperbaiki pertumbuhan rambut, peluruh kencing, mencegah kehamilan, pengerasan hati (cirrhosis), bengkak, gatal -gatal, radang mata (Hariana 2008).

\section{Waru (Hibiscus tiliaceus L.)}

Tumbuhan waru mengandung senyawa seperti saponin, flavonoid, tannin, skopoletin baru (hibiscusin), amida baru (hibiscusamide), asam fanilat, stigmasterol, campuran sitostenone. Waru biasanya digunakan sebagai obat batuk, diare berdarah, batuk, amandel, anti kanker, dan untuk menyuburkan rambut (Chen et al. 2006).

\section{Urang-aring (Eclipta alba L. Hassk)}

Pada etnis Jawa untuk penyubur rambut daun urang-aring dilakukan pengolahan dengan cara dihaluskan dan ditambahkan 2 gelas air, disaring, diembunkan semalam, kemudian dibasuhkan ke kulit kepala sambil dipijit (Veriana et al. 2011)

\section{Tumbuhan jenis paku-pakuan (Asplenium cf. phyllitidis)}

Tumbuhan jenis paku-pakuan ini dimanfaatkan oleh etnis Dayak Malinau sebagai obat penyubur rambut dengan cara daun ditumbuk sampai halus dan dicampur dengan parutan kelapa, airnya disaring dan digunakan sebagai pencuci rambut. Etnis Dayak Malinau memanfaatkan tanaman Gmelina sp sebagai obat penyubur rambut, dengan cara daun diremas, digosokkan pada kulit kepala (Karmilasanti \& Supartini 2011).

\section{Daun katuk (Souropus androgynus (L.) Merr )}

Etnis Using (Banyuwangi) menggunakan daun katuk sebai penyubur rambut. Kandungan kimia daun katuk adalah protein, lemak, kalsium, fosfat, besi, vitamin A, $B, C$, steroid, flavonoid dan polifenol. Pemanfaatan tanaman ini sebagai obat tradisional sangat bervariasi, seperti untuk pelancar ASI, obat demam, obat bisul dan darah kotor. Selain itu akarnya berkhasiat sebagai obat frambusia, susah kencing dan obat panas (Astuti et al. 1997). Daun katuk mengandung alpha-tocopherol yang tinggi, bahkan tertinggi dibandingkan dengan tanaman tropis lain yang dapat dikonsumsi. Kandungan tokoferol tersebut merupakan antioksidan yang dapat membantu menjaga kesehatan rambut (Subekti et al. 
2006). Daun katuk mengandung vitamin $C$ yang merupakan senyawa antioksidan sebesar $244 \mathrm{mg} / 100$ gram dimana kandungan ini melebihi kandungan pada jeruk, pepaya, jambu biji, dan bayam. Berdasarkan uji aktivitas antioksidan diketahui nilai IC50 daun katuk adalah $80.81 \mathrm{ppm}$ yang menandakan bahwa flavonoid dari daun katuk (Sauropus androgynus L.) memiliki kemampuan sebagai antioksidan yang kuat (Zuhra et al. 2008).

Pada etnis Bali untuk penumbuh rambut jumlah yang di perlukan setiap bahan adalah 1 ons, kecuali minyak kelapa 1 liter. Cara pengolahan pembuatan minyak sebagai penyubur rambut yaitu buah jarak dan kemiri disangrai sampai hitam, dicampur dengan daun mangkokan, daun teh-tehan, pandan arum, urangaring, lidah buaya, akar wangi, klabet, pacing, sandat, cempaka dan daun rambutan. Semua bahan tersebut dipanaskan dalam 1 liter minyak kelapa. Panaskan bahan-bahan tersebut dengan api kecil selama $6-8$ jam. Selanjutnya minyak siap untuk dikemas. Cara penggunaan minyak penyubur rambut dengan menggosokkan minyak pada kulit kepala sambil dipijatpijat (Gayatri et al. 2015).

Keterbatasan ulasan pembahasan dalam artikel ini pada beberapa tanaman obat yang disajikan pada tabel 1 yaitu bahwa informasi yang didapatkan tentang studi etnofarmasi dari tanaman obat sidaguri (Sida rhombifolia L.), jarak (Jatropha curcas L), pandan arum (Pandanus amaryllifolius), akar wangi (Vetiveria zizanioides), klabet (Trigonella foenum-graecum), sandat (Cananga odorata), cempaka (Magnolia liliifera), rambutan (Nephelium lappaceum) dan pulai (Alstonia scholaris (L.) R. Br.) yang berguna untuk perawatan dan penyubur rambut sumber informasi datanya masih terbatas dalam literatur publikasi sehingga sangat perlu dilakukan penelitian lanjutan mengenai studi etnofarmasi dari tanaman-tanaman obat tersebut.

\section{SIMPULAN}

Berdasarkan hasil kajian terhadap artikel studi etnofarmasi tumbuhan obat pada beberapa etnis di Indonesia, maka dapat disimpulkan bahwa terdapat 23 jenis tanaman dari 20 famili yang digunakan oleh beberapa etnis di Indonesia diantaranya Pulau Sumatera (etnis Aceh, etnis Melayu, etnis Rejang, etnis Mandailing, dan Kerinci), Pulau Sulawesi (etnis Kaili Ledo, etnis Kaili Moma, etnis Sigi, etnis Banggai, etnis Seko), Pulau Jawa dan Bali (etnis Jawa, etnis Using), etnis Bali, dan Pulau Kalimantan (etnis Dayak Malinau, Dayak Kanayant, Dayak Tunjung). Bagian yang berguna dari tanaman obat yang paling banyak digunakan untuk perawatan dan penyubur rambut adalah daun dan buah sedangkan untuk etnis yang terbanyak memanfaatkan tanaman obat untuk perawatan dan penyubur rambut adalah etnis Bali. Pengetahuan lokal (indigenous knowledge) etnis dalam pemanfaatan tumbuhan obat yang dimiliki oleh etnis-etnis di Indonesia menjadikan sumber bahan obat yang dapat dikaji lebih lanjut dalam rangka pencarian dan pengembangan alternatif pengobatan.

\section{UCAPAN TERIMA KASIH}

Ucapan terima kasih disampaikan kepada Kepala Badan Litbang Pertanian yang telah membiayai penelitian ini melalui KKP3SL, Kepala Balittro yang telah memberi fasilitas rumah kaca dan laboratorium, Kepala BPTP Jateng yang telah memberi ijin penelitian, serta Teknisi Litkayasa Balittro yang telah banyak membantu dalam pelaksanaan penelitian.

\section{DAFTAR PUSTAKA}

Helida A. et al. 2016. Retensi dan Perubahan Pengetahuan Etnobotani Masyarakat Kerinci seblat jurnal. krbogor. lipi. go. id. Buletin Kebun Raya. 19 (2):105-116

Arlene A. 2013. Ektraksi Kemiri dengan Metode Soxhlet dan Karakterisasi Minyak Kemiri. Jurnal Teknik Kimia USU. (2): 2. 6-10. UnPar: Bandung.

Astuti YB. Wahjoedi dan MW. Winarno. 1997. Efek diuretic infus akar katuk terhadap tikus putih. Warta Tumbuhan Obat. 3(3):42-43.

Azis, S., dan Muktiningsih. S.R. 1999. Studi Kegunaan Sediaan Rambut. Puslitbang Farmasi Badan Litbangkes. 9 (1):6-13.

Bodeker, G. 2000. Indigenous medical knowledge: the law and politics of protection. Oxford: Oxford Intelectual Property Research Centre Seminar in St. Peter's College.

Chen JJ, SY, CY, C IS, W TC, HY. 2006. A New Cytotoxic Amide From The Stem Wood of Hibiscus Tiliaceus. Jurnal Planta Med. 72(10):935-8.

Dalimartha S, Soedibyo, M. 1998. Perawatan Rambut dengan Tumbuhan Obat dan Diet Suplemen. Bogor (ID): PT. Penebar Swadaya. Halaman 160.

Dalimartha S, Soebidyo M. 1999. Perawatan Rambut Dengan Tumbuhan Obat dan Diet Suplemen. Jakarta (ID): Swadaya. Halaman 1-10, 28-33. 
Dalimartha S. 2003. Atlas Tumbuhan Obat Indonesia Jilid 3. Cetakan I. Jakarta (ID): Puspa Swara.

Dalimartha S. 2003. Atlas Tumbuhan Obat Indonesia. Jilid II. Jakarta (ID): Trubus Agriwidya.

Dianto I, Anam S, Khumaidi A. 2015. Studi Etnofarmasi Tumbuhan Berkhasiat Obat Pada Suku Kaili Ledo di Kabupaten Sigi, Provinsi Sulawesi Tengah. Galenika Journal of Pharmacy. 1 (2): 85-91

Efremila, Wardenaar, E, Sisillia L. 2015. Studi Etnobotani Tumbuhan Obat oleh Etnis Suku Dayak di Desa Kayu Tanam Kecamatan Mandor Kabupaten Landak. Jurnal Hutan Lestari. 3 (2) : 234-246

Elevitch CR, Manner HI. 2006. Traditional tree initiative: species profiles for Pacific Islands agroforestry. http://www.agroforestry.net/tti/ Aleuriteskukui.pdf

Fakhrozi I. 2009. Etnobotani Masyarakat Suku Melayu Tradisional Di Sekitar Taman Nasional Bukit Tigapuluh: Studi Kasus di Desa Rantau Langsat, Kec. Batang Gangsal, Kab. Indragiri Hulu, Provinsi Riau. [Skripsi]. Bogor (ID): Departemen Departemen Konservasi Sumberdaya Hutan dan Ekowisata Fakultas Kehutanan Institut Pertanian Bogor.

Gayatri et al 2015. Jenis - Jenis Tumbuhan yang Digunakan sebagai Bahan Perawatan Kecantikan di Puri Damai Desa Singakerta, Kecamatan Ubud, Kabupaten Gianyar. Jurnal Simbiosis III (1): 281290

Hariana A. 2008. Tumbuhan Obat dan Khasiatnya Seri 2 Cet. 6. Jakarta (ID): Penebar Swadaya.

Heinrich M, Bremner P. 2006. Ethnobotany and Ethnopharmacy - Their Role for Anti-Cancer Drug Development. Current Drug Targets. 7: 239-245.

Islami My, Ibrahim N, Nugrahani AW. 2017. Studi Etnofarmasi Suku Kaili Moma di Kecamatan Kulawi, Kabupaten Sigi, Provinsi Sulawesi Tengah. Galenika Journal of Pharmacy. Vol. 3 (1) : 27 - 33

Istriyani YY. 2011. Pengujian Kualitas Minyak Kemiri dengan Mengukur Putaran Optik Menggunakan Polarimeter. Tugas Akhir. Semarang (ID): Program Studi Diploma III Teknik Kimia, Program Diploma Fakultas Teknik, Universitas Diponegoro.

Karmilasanti, Supartini. 2011. Balai Besar Penelitian Dipterokarpa, Samarinda Keanekaragaman Jenis Tumbuhan Obat dan Pemanfaatannya di Kawasan Tane' Olen Desa Setulang Malinau, Kalimantan Timur. Jurnal Penelitian Dipterokarpa. 5 (1) Juni 2011.
Karina, Septi. 2014. Jenis Tumbuhan Berguna Pada Pekarangan Masyarakat Percampuran di Kelurahan Layana Indah Kecamatan Palu Timur Sulawesi Tengah. Biocelebes. 8(2): 1-12

Ketaren S. 1986. Pengantar Teknologi Minyak dan Lemak Pangan. Cetakan Pertama. Jakarta (ID): UIPress. Halaman: 13-14.

Khairiyah N, Anam S, Khumaidi A. 2016. Studi Etnofarmasi Tumbuhan Berkhasiat Obat Pada Suku Banggai di Kabupaten Banggai Laut, Provinsi Sulawesi Tengah. GALENIKA Journal of Pharmacy. 2(1) : $1-7$

Lestari AP, Rosyid A, Wahyudin I. 2016. Aktivitas Ekstrak Daun Cabe Rawit (Capsicum frutescens L.) terhadap Penghambatan Pertumbuhan Bakteri Escherichia coli Secara Invitro. Jurnal Farmasi Sains dan Praktis. 1(2): Februari 2016.

Marchaban JC, Soegiharto, Kumarawati FE. 2007. Uji Aktifitas Daun Randu (Ceiba pentandra Gaertn. ) Sebagai Penumbuh Rambut. UGM, Yogyakarta.

Mitsui T. 1992. New Cosmetic Science. Amsterdam (NL): Elsevier Science B. V. hlm 50.

Nilawati, Mubarrak J, Brahmana ME. 2017. Studi Etnobotani Tumbuhan Obat di Kecamatan Bangun Purba Kabupaten Rokan Hulu Provinsi Riau. Fakultas Keguruan dan Ilmu Pendidikan Universitas Pasir Pengaraian.

Pasorong SY, Tambaru E, Umar RM, \& Masniawati A. 2015. Identifikasi Tumbuhan Berkhasiat Obat dan Potensi Pemanfaatannya Pada Beberapa Desa di Sekitar Gunung Sesean Kabupaten Toraja Utara. [Skripsi]. Makassar (ID): Fakultas MIPA Jurusan Biologi, Universitas Hasanuddin.

Pieroni A, Quave C, Nebel S, Henrich M. 2002. Ethnopharmacy of the Ethnic Albanians (Arbereshe) of Northern Basilicata. Italy (IT). Fitoterapia. 72:217-241.

Prihandana et al. 2008. Bioetanol Ubi Kayu Bahan Bakar Masa Depan. Jakarta (ID): Agro Media Pustaka.

Priskila V. 2012. Uji Stabilitas Fisik dan Uji Aktivitas Pertumbuhan Rambut Tikus Putih Jantan dari Sediaan Hair Tonic yang Mengandung Ekstrak Air Bonggol Pisang Kepok (Musa balbisiana). [Skripsi]. Depok (ID): Fakultas MIPA Program Studi Farmasi, Universitas Indonesia. Halaman 62.

Putra WS. 2013. Sehat Tanpa Dokter Dengan Ramuan Herbal. Yogyakarta (ID):Citra Medika Pustaka. 
Rahayu S. 2007. Efek Campuran ekstrak Etanol Daun Mangkokan (Nortopanax scutellaarium Merr.) dan seledri (Apium graveolens Linn.) terhadap pertumbuhan rambut kelinci jantan. [Skripsi]. Bogor (ID): Fakultas Matematika dan IImu Pengetahuan Alam Program Studi Farmasi, Universitas Pakuan

Subekhi R, Sudarso, Hartanti D. 2009. Uji Pendahuluan Efek Hair Tonic Minyak Biji Wijen (Sesamum indicum L) Terhadap Pertumbuhan Rambut Kelinci Jantan. PHARMACY. 6(3).

Rele, Aarti S. Mohile RB. 2003. Effect of mineral oil, sunflower oil, and coconut oil on prevention of hair damage. Journal of Cosmetic Science. 54(2):175-92.

Robinson T. 1995. Kandungan Organik Tumbuhan Tinggi. Bandung (ID): ITB

Rosita, Rostiana, Pribadi, Hernani, 2007. Penggalian IPTEK etnomedisin di Gunung Gede Pangrango. Bulletin Littro. 18(1):13-28.

Sangat HM, Zuhud EAM, Damayanti K. 2000. Kamus penyakit dan tumbuhan obat Indonesia (etnofitomedika I). Jakarta (ID): Yayasan Obor Indonesia

Sastrapradja DS, Nagai S, Naito Y. 1986. Indek Tumbuh - Tumbuhan Obat di Indonesia. PT. Eisai Indonesia.

Sawaya ME. 1998. Novel Agents for The Treatment of Alopecia. Seminars in Cuntaneous Medicine and Surgery. Miami (FL): W.B. Saunders Company. Hal:7-12.

Setyowati MF. 2010. Etnofarmakologi dan Pemakaian Tanaman Obat Suku Dayak Tunjung di Kalimantan Timur. Media Litbang Kesehatan Volume. 20(3).

Subekti et al. 2006. Penggunaan Tepung Daun Katuk dan Ekstrak Daun Katuk (Sauropus androgynus L.Merr) sebagai Substitusi Ransum yang Dapat Menghasilkan Produk Puyuh Jepang Rendah Kolesterol. JITV. 11(4):254-259.

Syamsuhidayat SS, Hutapea JR. 1991. Inventaris Tumbuhan Obat Indonesia. Buku Dep.Kes. R.I. Jakarta (ID): Balitbangkes. Hal 616.

Tapundu et al. 2015. Studi Etnobotani Tumbuhan Obat Pada Suku Seko di Desa Tanah Harapan, Kabupaten Sigi, Sulawesi Tengah. Biocelebes. 9(2):66-86.

Tyler VE, Brady LR, Robbers JE. 1989. Pharmacognocy. U.S.A:Lea \& Febiger

Ulya ZA, Rusman. 2012. Cegah Diabetes Dengan Rempeyek Lidah Mertua. Sekolah Menengah Analisis Kimia. Jawa Barat.
Veriana T. 2014. Studi Etnobotani Tumbuhan Obat Tradisional Oleh Suku Jawa Dan Lembak Kelingi Di Kecamatan Sindang Kelingi Kabupaten Rejang Lebong Dan Implementasinya Pada Pembelajaran Biologi SMA. [Skripsi]. Bengkulu (ID): Program Studi Pendidikan Biologi, Fakultas Keguruan dan IImu Pendidikan, Universitas Bengkulu.

Winanti. 2005. Pengaruh Ekstrak Etanol Herba Seledri ( Apium graveolens Linn.) terhadap Kecepatan Pertumbuhan Rambut Kelinci Jantan dan Profil Kromatografi Lapis Tipisnya. [Skripsi]. Surakarta (ID): Fakultas Farmasi Universitas Muhammadiyah Surakarta.

Winda et al. 2014. Etnobotani Bahan Kosmetik oleh Masyarakat Using di Kabupaten Banyuwangi sebagai Bahan Ajar Populer. Pancaran. 3(3): 53-62.

Windardi FI, Rahayu M, Uji T, Rustiami. 2006. Pemanfaatan Tumbuhan sebagai Bahan Obat oleh Masyarakat Lokal Suku Muna di Kecamatan Wakarumba Kabupaten Muna Sulawesi Utara. Biodiversitas. 7(4): 333-339.

Widyaningrum H. 2011. Kitab tanaman Obat Nusantara. Yogyakarta (ID) : Media Pressindo.

Yatias AE. 2015. Etnobotani Tumbuhan obat di Desa Neglasari Kecamatan Nyalindung Kabupaten Sukabumi Provinsi Jawa Barat. [Skripsi]. Jakarta (ID): Jurusan Biologi Fakultas Sains dan Teknologi, Universitas Islam Negeri Syarif Hidayatullah Jakarta.

Yunita. 2012. Uji Aktivitas Antioksidan Ekstrak dan Fraksi Ekstrak daun Cabe Rawit (Capsicum frustescens L.) dan Identifikasi Golongan Senyawa dari Fraksi Teraktif. [Skripsi]. Depok (ID): Fakultas Matematika dan Ilmu Pengetahuan Alam, Universitas Indonesia.

Zuhra et al. 2008. Aktivitas Antioksidan Senyawa Flavonoid dari Daun Katuk (Sauropus androgunus (L) Merr.). Jurnal Biologi Sumatera. 3(1):7 - 10

Zuriana S, Irvianty. 2014. Kajian Jenis-jenis Tumbuhan yang dimanfaatkan sebagai Obat oleh Masyarakat di Kota Sabang, hal. 376. Di dalam Optimalisasi Riset Biologi Dalam Bidang Pertanian, Peternakan, Perikanan, Kelautan, Kehutanan, Farmasi dan Kedokteran. Prosiding Seminar Nasional Biologi. 15 Februari 2014. Medan (ID): USU Press. 